\title{
EDUCATIONAL SOFTWARE DEVELOPMENT PROJECT - EDUCATIONAL PORTAL
}

\author{
Francely do Nascimento Gomes ${ }^{1}$, David Barbosa de Alencar ${ }^{2}$, Fábio Soares de Oliveira ${ }^{3}$, Maria \\ Cristiane Bandeira Santos ${ }^{4}$, Valquiria Delani Alves Dias ${ }^{5}$, Camily Murrieta Vasconcelos Oliveira \\ Bezerra $^{6}$ and Igor Felipe Oliveira Bezerra ${ }^{7}$
}

\author{
1, 2, 3, 4, 5 Braulo Cardoso de Mattos Higher Education Institute - FASERRA. Manaus-Amazonas, Brazil. \\ ${ }^{6}$ Municipal Secretary of Education of Manaus - SEMED. Manaus-Amazonas, Brazil. \\ ${ }^{7}$ Nilton Lins University. Manaus-Amazonas, Brazil.
}

Email: franalex_@hotmail.com, david002870@hotmail.com, fbsoares171@gmail.com, cristiane.engenheiracivil@gmail.com, valquiria.delani7@gmail.com, camilymv@hotmail.com, igor.bezerra@uniniltonlins.edu.br

Received: Aug $23^{\text {th }}, 2019$

Accepted: Aug 30th, 2019

Published: December 02 ${ }^{\text {th }}, 2019$

Copyright (C2016 by authors and Galileo Institute of Technology and Education of the Amazon (ITEGAM).

This work is licensed under the Creative Commons Attribution International

License (CC BY 4.0).

https://creativecommons.org/licen ses/by/4.0/

\section{Opea Aceces:}

\section{INTRODUTION}

At present, there are changes in various aspects in the individual's life such as cultural, technological, political, economic, social, etc., they are occurring at increasing speed. According to [1], in general, we often associate significant changes with project outcomes. Secondly [2], as a consequence, managing projects efficiently in this age of great change is one of the great challenges of the executive of modern times.

In the context mentioned above, this study will constitute a research project as the main guide the development of an Educational Software - computer program, to support teachers and students in all teaching subjects. This software aims to assist the teaching and practices in a participatory way, providing the conquest of knowledge. Overcoming this challenge is being willing to manage projects in a planned and professional manner.

Today education does not reach the villages of this region despite the existence of Distance Education (ODL). In this segment, this software can be an incentive for teaching and extracurricular activities contributing to the formation of the "man" as a citizen. The execution of this project is relevant for both technology and education. The Portal do Ensino educational software development project will assist in learning and address the imperfections processed during this study.

The integration of the computer with the community is necessary in the educational process, as students can learn to use the computer with the visuals that the software will present, making learning much more interesting in a positive and effective way. This study is conducted to investigate the following research question: How the educational software development project can assist in improving the educational teaching process in Distance Education (ODL).

This article exposes what the researcher intends to accomplish during the study, where he develops an educational software project Portal do Ensino assisting in the action of knowledge and providing the failures that happened during this learning. The main objective is to facilitate the understanding of the subjects, helping teachers and students in the performance of teaching. 


\section{BIBLIOGRAPHIC REFERENCE}

\section{II.1 PROJECT MANAGEMENT}

Project management experience is increasingly being revealed and demanded by companies to employees, where today there are few companies that do not use "Project Management" and can make positive conclusions without wasting time and money. Learning the techniques and best practice in PMBOK bundled with the project management tool is an implementation designed to meet the attribute of the company's projects achieving quality assurance. Proper project management ensures customer satisfaction by meeting the scope, time and cost of the project making projects profitable.

According to [3], the joint venture has a smaller difference compared to a company that has a degree of excellence in project management in the way that the stages of growth and balance of the project management life cycle are put into practice. It is at this point that the application of concepts has its greatest impact on project management.

Project management is a set of management tools that enable a company to develop a set of skills, including individual knowledge and capabilities, for controlling unique, complex nonrepetitive events within a predetermined time, cost and quality scenario. [4]

In August 1987, PMI published a document called The Project Management Body of Knowledge, which was revised and reissued in 1996 under the name of A Guide to the Project Management Body of Knowledge (PMBOK) and was updated in 2000. 2004 and 2008.

The project comprises the gathering of information where the main control of activities takes place using PMBOK best practices and its processes, bringing the development of educational software to support the subjects, as well as: Portuguese, mathematics, science, history, geography, reciprocal way supporting learning in ODL.

[5] recommends which processes need to be executed throughout project management execution in the areas of scope, time, cost, human resources, communications, risk, and procurement. For this purpose, a project management knowledge guide (PMBOK Guide) was created, identifying its usual elements where they are divided as follows: Project management processes are: Start, Planning, Execution, Monitoring and Control, Closure.

Project management is comprised of such areas as Integration Management, Scope Management, Time Management, Cost Management, Quality Management, Human Resource Management, Communications Management, Risk Management, Procurement Management.

Project management brings a unique focus laid out by the objectives, resources and schedule of each project and is true to its rapid growth, as people have been practicing and studying Project Management in the most diverse areas, such as aerospace, automotive, administration, construction., engineering, financial services, information technology, pharmaceuticals and telecommunications. All knowledge gained is reaffirmed and not only limited to traditional practices, but also innovative and advanced.

The PMBOK is constantly evolving and as a result has several published materials, as well as several updated magazine editions.

According to [6] Project Management is the "application of knowledge, skills, tools and techniques to project activities, with a view to meeting the requirements in question". [5] provides that Project Management is the art of coordinating activities aimed at meeting the expectations of individuals and organizations directly involved in the project or those whose interests may be positively or negatively affected during or after the project. your conclusion.

In the "Construction Glossary" of the International Association for Professional Management of Construction [7], the following definition for project management "addresses the overall planning and coordination of a project from beginning to end, aimed at identifying requirements. and completion, ensuring compliance with schedule, costs and quality standards."

Integrated processes refer to the integration of project management with other administrative processes, such as Total Quality Management (TQM), concurrent engineering, reengineering, change management, risk management, among others [8].

With respect to culture, every organization looks for one that is capable of rapidly changing according to the needs of each project and adapting equally quickly to a constantly changing dynamic environment. It is imperative that the culture of each organization underpins the core values of project management, such as cooperation, teamwork, trust and more efficient communications.

According to [8] "visible and indispensable managerial support for the continuity of the project management culture". However, many companies understand that the failure of a project is mainly due to discouragement among employees, negative interpersonal relationships, lack of commitment to project objectives, causing the manager to become a conflict manager.

\section{MATERIAL AND METHODS}

In the study, it was necessary to use the software support tool Open Project, to organize the proper information collected in the development of all project management. The PMBOK® Guide PMI 4th Edition, which guides you on the right track of best practices for project management, as well as the organization of the entire project, is also a guide. Within the Guide.

\section{STUDY APPLICATION}

Project quality management was performed based on ISO 9001: 2008, as it acts in accordance with it in all its processes. Check applications for software: Time of handling a request for change in service levels; Customer satisfaction survey frequency; Time taken to raise issues related to service levels and Impact of quality of additional financial resources to meet defined service level.

Quality metrics allow us to indicate the level of software response to explicit and implicit customer requirements, which we define through quality management which are:

- Correctitude: The program must operate correctly, otherwise it will have little value to its users.

- Maintainability: The ease with which the program can be fixed if an error occurs.

- Integrity: Attribute that measures the ability of the software to withstand attacks on its integrity such as data and documents.

- Usability: If a program is not easy and user-friendly to use, it will not succeed even if the functions it performs are perfect.

All claims made, as well as products and / or deliveries that do not comply with the Scope Statement, should be treated as corrective measures in the quality management plan, after CCM assessment. And any changes in quality requirements initially anticipated for the project must be evaluated and classified within the quality change control system (SCMQ). 
Changes in quality standards will be considered only as corrective measures which, if influencing the success of the project, should be integrated into the plan. Innovations and new levels of quality will not be considered by quality management. All quality change requests must be made in writing or by email as described in the project communications plan.

\section{RESULTS / DISCUSSIONS}

With the help of the PMBOK4 guide you do not have to apply all the best practices but check which ones are necessary to fit the process. The 4th edition of the PMBOK Guide says that the project is unique and temporary, because each time it is executed it will have a difference in the context, because it will be the different people who will practice the project, such as suppliers, deadlines, values, different circumstances causing this. make it different from the previous one. The guide is made up of good practices designed to create a unique product or service. It is understood that a project has a very definite beginning and end having a precise domain and as the rules are planned, executed and controlled.

According to [9], project management, among other actions, identifies requirements, supports the different needs, concerns and expectations of stakeholders, as well as pursues the balance of conflicting constraints that involve scope, quality, schedule, budget, resources and risks. The contained management processes are linked in the initiation, planning, execution, monitoring and control, and closure phases - which constitute the life cycle of a project.

In this context, special attention should be given to the set of risks inherent in a project. Project management should contribute to the risk of failure as low as necessary. According to [9], risk is an uncertain event or condition that may belong to one or more project objectives such as scope, schedule, cost and quality.

Communications management costs will be considered as basic project costs. For priority needs that are beyond the scope of the project manager's competence, or when there is no more managerial reserve available, it will apply to the sponsor trigger, and as the project manager has no autonomy necessary to decide to use the project manager reserve. risk contingency in communications management. Regarding the costs, we have the following survey:

Table 1: Project Collaborating Costs.

\begin{tabular}{|c|l|c|c|c|c|}
\hline $\mathrm{N}^{\circ}$ & \multicolumn{1}{|c|}{ Professional } & $\mathrm{R} \$ / \mathrm{h}$ & $\begin{array}{c}\text { Amo } \\
\text { unt }\end{array}$ & $\begin{array}{c}\text { Unit of } \\
\text { measurement }\end{array}$ & Total \\
\hline 1 & Project Manager & 80,00 & 140 & Hours & $\begin{array}{c}\mathrm{R} \$ \\
11.200,00\end{array}$ \\
\hline 2 & Systems Analyst & 50,00 & 200 & Hours & $\begin{array}{c}\mathrm{R} \$ \\
10.000,00\end{array}$ \\
\hline 3 & $\begin{array}{l}\text { Developer and } \\
\text { Programmer }\end{array}$ & 60,00 & 210 & Hours & $\begin{array}{c}\mathrm{R} \$ \\
12.600,00\end{array}$ \\
\hline & \multicolumn{5}{|c|}{ TOTAL } \\
$\begin{array}{c}\mathrm{R} \$ \\
33.800,00\end{array}$ \\
\hline
\end{tabular}

Source: Authors, (2019).

Table 2: Extra Costs.

\begin{tabular}{|c|c|c|}
\hline $\mathbf{N}^{\mathbf{0}}$ & ACTIVITY & TOTAL \\
\hline 1 & $\begin{array}{c}\text { Data Collection - Amazon Terms } \\
\text { Search }\end{array}$ & 900,00 \\
\hline 2 & Search Difficulties & $2.000,00$ \\
\hline 3 & Software Development & $3.200,00$ \\
\hline 4 & $\begin{array}{c}\text { Infrastructure and Human Resources } \\
\text { Request }\end{array}$ & $10.000,00$ \\
\hline 5 & Software Testing \& Training & 500,00 \\
\hline 6 & Software Implementation & 800,00 \\
\hline \multicolumn{2}{|c|}{ TOTAL } & $17.900,00$ \\
\hline
\end{tabular}

Source: Authors, (2019).
Table 3: Summary of Costs.

\begin{tabular}{|c|c|c|}
\hline $\mathbf{N}^{\mathbf{0}}$ & ITEMS & TOTAL (R\$) \\
\hline 1 & $\begin{array}{c}\text { Project Human Resource } \\
\text { Cost }\end{array}$ & $32.500,00$ \\
\hline 2 & Extra Costs & $10.000,00$ \\
\hline \multicolumn{2}{|c|}{ TOTAL } & $42.500,00$ \\
\hline
\end{tabular}

Source: Authors, (2019).

Table 4: Cash Flow.

\begin{tabular}{|c|c|c|}
\hline $\mathbf{N}^{\circ}$ & ATIVIDADE & TOTAL \\
\hline 1.1 & Check Amazon Terms & 500,00 \\
\hline 1.2 & $\begin{array}{l}\text { Understand and replace words } \\
\text { according to meanings }\end{array}$ & 500,00 \\
\hline 2.1 & Evaluate teachers & $1.000,00$ \\
\hline 2.1 .1 & Search for teaching difficulties & 500,00 \\
\hline 2.1 .2 & Search themes and content & 500,00 \\
\hline 2.2 & Evaluate students & 500,00 \\
\hline 2.2 .1 & Search for learning disabilities & 250,00 \\
\hline 2.2 .2 & $\begin{array}{l}\text { Search for topics and content } \\
\text { needed to make learning easier }\end{array}$ & 250,00 \\
\hline 3.1 & Check Search & 250,00 \\
\hline 3.1 .1 & $\begin{array}{c}\text { Search Technical Terms and } \\
\text { Amazon Terms }\end{array}$ & 250,00 \\
\hline 3.2 & $\begin{array}{c}\text { Raise content related to each } \\
\text { subject }\end{array}$ & 250,00 \\
\hline 3.2 .1 & $\begin{array}{l}\text { Select these contents according } \\
\text { to the difficulties }\end{array}$ & 250,00 \\
\hline 3.3 & $\begin{array}{l}\text { Collect information and images } \\
\text { for the software }\end{array}$ & 750,00 \\
\hline 3.3 .1 & Select images for software & 250,00 \\
\hline 3.4 & Develop & $1.500,00$ \\
\hline 3.4 .1 & $\begin{array}{l}\text { Select the language that the } \\
\text { software will be developed }\end{array}$ & $1.000,00$ \\
\hline 4.1 & Order machinery and equipment & $5.000,00$ \\
\hline 4.1.1 & $\begin{array}{c}\text { Check Software Compatible } \\
\text { Settings }\end{array}$ & 200,00 \\
\hline 4.2 & Request IT Infrastructure & 250,00 \\
\hline 4.2 .1 & $\begin{array}{l}\text { Check the number of machines, } \\
\text { equipment and software needed } \\
\text { to run the educational software. }\end{array}$ & 200,00 \\
\hline 4.3 & Request Human Resources & 300,00 \\
\hline 4.3.1 & $\begin{array}{l}\text { Hire teachers and monitors for } \\
\text { the computer lab }\end{array}$ & $4.050,00$ \\
\hline 5.1 & Run tests with teachers & 200,00 \\
\hline 5.2 & Run tests with students & 200,00 \\
\hline 5.3 & Train teachers and monitors & 200,00 \\
\hline 6.1 & $\begin{array}{l}\text { Implement the software in } \\
\text { schools in riverside } \\
\text { communities }\end{array}$ & 900,00 \\
\hline \multicolumn{2}{|r|}{ TOTAL } & $\begin{array}{c}20.000,0 \\
0\end{array}$ \\
\hline
\end{tabular}

Source: Authors, (2019).

There is another important presentation of project management that talks about time, scope, cost and quality constraints, these are interdependent elements that face the success of a project for a good result. Thus, when there is any change in any of them, the others are impacted.

Project management and management have become very important in the organization, as the manager can strategically reconcile information from other sectors throughout the project. 
Training and teaching are useful for those interested in supporting project management as a profession. Quality of training and development, along with executive support, are the two most important factors for organizations to achieve successful Project Management and therefore excellence.

Informal project management is based on four basic elements: trust, communication, cooperation, and teamwork. Formality is represented by policies and procedures and informality is represented by checklists. That is, informality does not eliminate all documentation but reduces it to minimally acceptable levels. Therefore, the larger the company size, the greater the tendency to use formal project management [10].

\section{FINAL CONSIDERATIONS}

This research presented the project management study, highlighting the development of the analytical structure, with defined and structured processes. It showed in a simple and objective way that Project Management is a strategic tool to be used in the business plan of organizations, because the results show a path that aims at better quality and productivity conditions in project companies, besides improving the final product.

The integration of the computer with the community is necessary for the educational process where students can learn to handle the computer and still learn by "playing" with the visuals that the software presents, making learning much more interesting in a positive and effective way. The software may be used as a source of research or any other complementary activity. For a better integration of the activities between the subjects, the teachers must architect the approach of the subject as a complement of the discipline taught in the classroom.

The training was necessary by qualifying the teachers, who should be the facilitators in this process, taking into account the integration between their teaching proposal and the informatics, where they should be willing to clarify all doubts and should encourage the use of this new program. It is also noted that a good knowledge in project management is not enough to succeed in an enterprise. There are external factors that can directly influence the entire process of development and execution.

In this way, it is possible to confirm how much it is necessary to have a well-defined analytical structure in your activities, because once defined, these will be allocated in the project schedule, defining times, resources and project completion. It is not just about theories, but about finding from the research done, which are extremely important to the success of a project.

The success of a Project Management becomes essential so that in future negotiations, organizations can act strategically, highlighting cost reduction as well as meeting deadlines with quality, obtaining advantages in the effective relationship with those involved in the project, known as stakeholders.

\section{REFERENCES}

[1] Vieira, E. Gerenciando Projetos na Era de Grandes Mudanças Uma breve abordagem do panorama atual. PMI Journal - PMI-RS 3, 2002, pp. 7-16.

[2] Kerzner, H. Gestão de projetos: as melhores práticas. 2. ed. Porto Alegre: Bookman, 2006.

[3] Keeling, Ralph. Gestão de projetos. Editora Saraiva, 2017.

[4] Menezes, LC de M. Gestão de projetos. Catho, 2006.
[5] Rose, Kenneth H. A Guide to the Project Management Body of Knowledge (PMBOK® Guide)-Fifth Edition. Project management journal, 2013, 44.3: e1-e1.

[6] Heldman, K. Gerência de projetos: guia para o exame oficial do PMI. 3. ed. Rio de Janeiro: Elsevier, 2006.

[7] Iapcm, International Association for Professional Management of Construction. Glossary of Construction. CM Glossary. 2003.

[8] Kerzner, Harold. Gestão de Projetos-: As Melhores Práticas. Bookman Editora, 2016.

[9] Quarti, Deinyffer Marangoni; Zilli, Julio Cesar. Gerenciamento de projetos na gestão organizacional: aplicação dos fundamentos do PMBOK em uma associação empresarial. Revista Foco, 2019, 12.2: $147-167$.

[10] Martins, L.; Gestão Profissional de Projetos. 2003. 